IZA DP No. 4348

Complements or Substitutes?

Task Specialization by Gender and Nativity in Spain

Catalina Amuedo-Dorantes

Sara de la Rica

August 2009

Forschungsinstitut zur Zukunft der Arbeit Institute for the Study of Labor 


\title{
Complements or Substitutes? Task Specialization by Gender and Nativity in Spain
}

\author{
Catalina Amuedo-Dorantes \\ San Diego State University, \\ CReAM, FEDEA and IZA \\ Sara de la Rica \\ Universidad del País Vasco, \\ CReAM, FEDEA and IZA
}

Discussion Paper No. 4348

August 2009

\author{
IZA \\ P.O. Box 7240 \\ 53072 Bonn \\ Germany \\ Phone: +49-228-3894-0 \\ Fax: +49-228-3894-180 \\ E-mail: iza@iza.org
}

\begin{abstract}
Any opinions expressed here are those of the author(s) and not those of IZA. Research published in this series may include views on policy, but the institute itself takes no institutional policy positions.

The Institute for the Study of Labor (IZA) in Bonn is a local and virtual international research center and a place of communication between science, politics and business. IZA is an independent nonprofit organization supported by Deutsche Post Foundation. The center is associated with the University of Bonn and offers a stimulating research environment through its international network, workshops and conferences, data service, project support, research visits and doctoral program. IZA engages in (i) original and internationally competitive research in all fields of labor economics, (ii) development of policy concepts, and (iii) dissemination of research results and concepts to the interested public.
\end{abstract}

IZA Discussion Papers often represent preliminary work and are circulated to encourage discussion. Citation of such a paper should account for its provisional character. A revised version may be available directly from the author. 


\section{ABSTRACT \\ Complements or Substitutes? \\ Task Specialization by Gender and Nativity in Spain*}

Learning about the impact of immigration on the labor market outcomes of natives is a topic of major concern for immigrant-receiving countries. There exists an extensive literature evaluating the impact of immigration on the employment and wages of natives in the U.S. Yet, despite the significant degree of occupational segregation by gender regardless of workers' origin, the literature has traditionally treated male and female immigrants as a homogenous group when examining the impact of immigration on native workers. Instead, using data from Spain, where the immigrant population has risen from 4 percent to 10 percent of the population within a decade, we allow for male and female foreign-born workers to have distinct impacts on the employment patterns of native men and women. This proves to be important as foreign-born workers only seem to have a significant impact on the employment pattern of native workers of the same sex. Furthermore, foreign-born male (female) workers do not appear to be perfect substitutes of similarly skilled native male (female) workers, which may help explain the null or small impacts of immigration on native employment and wages. Instead, immigration appears to have affected the task specialization and occupational distribution of natives of the same gender.

JEL Classification: F22, J61, J31, R13

Keywords: immigration, gender, task specialization, complements, substitutes, Spain

Corresponding author:

Catalina Amuedo-Dorantes

Department of Economics

San Diego State University

5500 Campanile Drive

San Diego, CA 92182

USA

E-mail: catalina.amuedo.dorantes@gmail.com

\footnotetext{
*We are grateful to David Autor, David Dorn, Giovanni Peri, Chad Sparber and seminar participants at UC Berkeley and at British Columbia University.
} 


\section{Introduction}

The impact of immigration on the host country's labor market is a topic of major concern for many immigrant-receiving nations. There is a large and growing literature on the consequences of migration on the employment and wages of native workers in the U.S. (see Borjas (1994, 1995, 1999, 2003, 2005), Borjas and Katz (2007), Card (1990, 2001, 2005), Card and Di Nardo (2000), Card and Lewis (2007), Lewis (2003), Ottaviano and Peri (2005, 2006), among others). In general, this literature finds that immigration appears to have small wage effects and no employment effects on natives. As noted by Ottaviano and Peri (2006), this is not surprising given that the effect of immigration depends on the degree of substitution between native and immigrant workers within educational groups. If native and immigrant workers of similar educational attainment posses productive skills that lead them to specialize in different occupations, it is reasonable to find a null to small impact of immigration on the employment and wages of natives as immigrants and natives are not competing for the same jobs. In this vein, Peri and Sparber (2008) recently show for the U.S. that less-educated natives adjust to an increase in less-educated immigrant workers by changing their task specialization and upgrading their occupations. Yet, despite the significant degree of occupational segregation by gender regardless of workers' origin, the literature has traditionally treated male and female immigrants as a homogenous group when examining the impact of immigration on native workers.

We add to the existing literature on two grounds. First, we allow for male and female foreign-born workers to have distinct impacts on the employment patterns of native men and women. This proves to be important as foreign-born workers only seem to have a significant impact on the employment pattern of native workers of the same sex. Second, instead of looking at the U.S., we focus on a European country with one of the largest influx of immigrants in the past decades, i.e. Spain. Spain constitutes an interesting and almost 
unprecedented case study given the impressive growth of its immigrant population over the past 15 years. In 1991, only 1.2 percent of the Spanish adult population (about 300,000 individuals) was foreign-born. Within a decade, this percentage quadrupled to 4.0 percent (1,370,000 individuals) and, by 2008, it had roughly reached 11 percent (5,200,000 individuals). In fact, since the year 2000, Spain has displayed one of the largest rates of immigration in the world -three to four times as large as the average immigration rate in the U.S. As in the U.S., the immigration literature focusing on Spain has failed to find much of an immigration impact on the employment and wages of natives. ${ }^{1}$ Hence, we explore whether such findings are partially due to the fact that immigrant and native workers do not compete for the same jobs. Theoretically, we follow Peri and Sparber (2008) and assume that immigrants, relative to natives, have a comparative advantage in manual as opposed to interactive or communication tasks. This comparative advantage causes: (i) immigrants to specialize in jobs that require more manual as opposed to non-manual skills and (ii) natives to respond to the lower wages that result from the increased labor supply in such jobs by shifting to occupations with a lower manual to non-manual task ratio.

We first find that, owing to occupational segregation by gender, the impact of immigrant men on the occupational distribution of native women is negligible, just as the impact of immigrant women is insignificant on the occupational distribution of native men. Secondly, foreign-born male (female) workers do not appear to be perfect substitutes of similarly skilled native male (female) workers, which may help explain the null or small impacts of immigration on native employment and wages. Instead, immigration appears to have affected the task specialization and occupational distribution of natives. Specifically, native men (women) relocate to jobs with a lower manual, as opposed to interactive or

\footnotetext{
${ }^{1}$ Empirical evidence on the impact of immigration on the wages of Spanish natives is very scarce given the lack of adequate wage data for a sufficient number of years. A few studies point out the small impact of immigration on the wages of Spanish natives (see Amuedo-Dorantes and De la Rica (2008), González and Ortega (2007), and Carrasco et al. (2008)). Yet, these results must be taken with caution given the data limitations.
} 
communication, ${ }^{2}$ content in response to increases in male (female) immigration. In terms of occupations, male immigration seems to have reduced the fraction of native men in skilled blue-collar jobs (e.g. craftsmen, operators and assemblers) and non-skilled blue-collar jobs (e.g. laborers), and raised it in skilled white-collar jobs (e.g. managerial and professional occupations). In turn, female immigration has contributed to reducing the presence of native women in non-skilled blue-collar jobs (mainly in domestic service) and increased it in skilled white-collar jobs (mostly in teaching and nursing).

The rest of the paper is organized as follows. Section 2 presents some descriptive evidence of changes in the relative supply of native and immigrant labor in blue and whitecollar occupations, as well as more detailed information regarding the occupational distribution and the task content of each occupation held by native men, native women, immigrant men and immigrant women. The theoretical framework upon which we base the empirical analysis is reviewed in Section 3 and a detailed description of the data is presented in Section 4. Section 5 discusses the methodology and our findings with regards to natives’ task specialization as immigration rises, whereas Section 6 looks more closely into the occupations natives are leaving and getting into. Section 7 concludes the study.

\section{Recent Evidence on Occupational Segregation by Gender and Navity}

\subsection{Differences in the Occupational Distribution of Workers by Gender and Nativity}

Two of the key assumptions in our empirical analysis are that, due to differences in their comparative advantages when it comes to performing manual as opposed to non-manual tasks, both native men (women) and immigrant men (women) as well as men and women (regardless of their nativity) differ in their occupation choices. Table 1 shows the occupational distribution of non-university workers over the time period under analysis, i.e. 1999 through 2007, using the 2-digit International Standard Classification of Occupations

\footnotetext{
${ }^{2}$ Throughout the paper, we use the terms “interactive”, “communication” and "non-manual” interchangeably.
} 
(ISCO-88). We have in bold those occupations with at least 5 percent of native men, native women, immigrant men or immigrant women. A quick inspection of the figures in Table 1 reveals significant differences in the employment patterns of each of the four aforementioned demographic groups. In particular, to make comparisons easier, Table 2 groups the most representative native occupations in bold in Table 1 -what we refer to as "Most Common Native Male (Female) Occupations”- into four categories: (i) Skilled white-collar jobs, (ii) Non-skilled white-collar jobs, (iii) Skilled blue-collar jobs and (iv) Non-skilled blue-collar jobs. $^{3}$

Two key findings are worth discussing. First, there is a significant degree of occupational segregation by gender, which calls for a separate analysis of men and women. For instance, the fraction of male workers holding traditionally male occupations is quite high (79 percent for natives and 88 percent for immigrants), whereas the percentage of them holding traditionally female occupations is quite low (30 percent of native men and 16 percent of immigrant men). The opposite is also true for women. The fraction of female workers employed in traditionally female occupations is quite high (78 percent of native women and 86 percent of immigrant women) relative to the percentage of women in traditionally male occupations (48 percent for natives and 30 percent for immigrants).

Second, there also exists a significant degree of occupational segregation by nativity. For instance, in the case of men, more than 30 percent of immigrant men with traditionally male jobs are concentrated in non-skilled blue-collar occupations relative to less than 10 percent of native men. In contrast, native men with traditionally male jobs display a significantly higher concentration in skilled white-collar jobs (more than 10 percent) relative to less than 3 percent of immigrant men. Likewise, in the case of women employed in

\footnotetext{
${ }^{3}$ Occupations coded 11 through 39 using the 2-digit ISCO-88 classification in Table 1 are included within the "skilled white-collar" category. Those coded between 40 and 59 are included within the "non-skilled whitecollar" category. Occupations coded 59 to 89 are grouped into the "skilled blue-collar" category and occupations coded 90 and up are classified under the "non-skilled blue-collar" category.
} 
traditionally female jobs (i.e. the vast majority of them), ${ }^{4}$ immigrant women display a significantly higher concentration in blue-collar jobs (in excess of 50 percent) compared to native women (about 20 percent hold such jobs). Yet, immigrant women have a significantly lower presence in skilled white-collar jobs (where only 2.2 percent of them are employed relative to 13.3 percent of their native counterparts).

\subsection{Changes in the Occupational Distribution of Workers by Gender and Nativity}

The figures in Table 1 and Table 2 underscore the extent of occupational segregation by gender and nativity characterizing the Spanish labor market over the time period under consideration. However, it is also interesting to explore how the aforementioned occupational differences have changed over time. Figures 1 and 2 do so by depicting changes in the relative distribution of less-educated workers in white-collar (as opposed to blue-collar) occupations over the 1999-2007 period.

There are a couple of facts worth noting from the two graphs. First, just as noted by the figures in Table 1 and Table 2, there has been a persistently high occupational segregation by gender evident from the fact that the fraction of native men in white-collar jobs is about half the fraction of native women in such occupations. This gender difference is also seen among immigrants despite the greater fluctuations in the fraction of immigrant men holding white-collar jobs over the time period under consideration.

Second, Figure 1 depicts a significant reduction in the fraction of immigrant men holding white-collar jobs after the year 2000 that occurs at a time when the percentage of native men holding such jobs slightly rises. Similarly, Figure 2 shows a slight increase in the fraction of native women holding white-collar jobs after the year 2000, whereas the percentage of immigrant women in white-collar jobs dropped after the year 2000 and did not

\footnotetext{
${ }^{4}$ In the case of women, we have not distinguished skilled from non-skilled blue-collar occupations because of the small fraction of women in skilled blue-collar occupations (those coded 60 through 89 using the ISCO-88 classification) as can be seen in Table 2.
} 
recover its 1999 level until the year 2007. In other words, it appears as if the concentration of native workers in white-collar jobs has slightly increased during the high-immigration period. These are, of course, descriptive statistics that could be masking the effect of a concurrent event responsible for the observed changes in the native occupational distribution at a time when immigration is rising, such as changes in the educational attainment of younger native cohorts or ongoing technological change. Hence, we will further explore these differences in the following sections using more suitable econometric techniques.

\section{Theoretical Framework}

In this section, we sketch the main elements and predictions of the general equilibrium model developed by Peri and Sparber (2008) on which we rely upon in the empirical analysis. In their model, immigrants have a comparative advantage in performing manual, as opposed to interactive or communication-intensive, tasks owing to their limited language proficiency and their often missing host country specific human capital skills. Given these comparative advantage differences, Peri and Sparber (2008) solve for the equilibrium provision of relative manual to interactive tasks by natives and derive some testable hypotheses regarding the impact of low-skill immigration on such provisions. The basic implications of their model can be easily described by Figure 3, which illustrates how the labor market equilibrium changes in response to an inflow of immigrants with a comparative advantage in manual (versus non-manual) tasks. At the initial equilibrium, the supply and demand of relative manual to non-manual tasks determine the equilibrium compensation of manual to nonmanual tasks $\left(\mathrm{w}_{\mathrm{m}} / \mathrm{w}_{\mathrm{nm}}\right)$. An inflow of immigrants with a comparative advantage in manual tasks shifts the relative supply of manual to non-manual tasks from immigrants to the right of the one from natives and, as a result, the overall relative supply of manual to non-manual tasks -a weighted average of the native and immigrant relative supplies- also shifts to the right. At the new and lower equilibrium relative compensation, the relative supply of manual 
to non-manual tasks by natives drops. Therefore, an inflow of immigrants with a comparative advantage in manual tasks induces native workers to relocate to occupations with a lower manual to non-manual task ratio. This is the hypothesis object of analysis in this paper, which we examine separately for native and immigrant men and for native and immigrant women.

\section{Data}

We use the 1999-2007 Spanish Current Population Survey (Encuesta de Población Activa, EPA) for the analysis since it provides the most representative sample of the Spanish workforce. We restrict our analysis to recent immigration inflows as recent immigrants (i.e. those with five or fewer years in Spain - around 65 percent of all immigrants in Spain) are less likely to have yet acquired the language proficiency and other Spanish-specific human capital skills (not exclusively related to language abilities) of natives. As a result, they are less likely to display a comparative advantage in interactive or communication tasks relative to natives. Additionally, since the vast majority of immigrants are employed in low skill jobs and we want to look at the occupational changes of native workers as a result of immigration, we focus primarily on workers without a university education. ${ }^{5}$

Table 3 presents some descriptive statistics. Our sample of recent immigrants is the group of individuals holding a foreign nationality ${ }^{6}$ and with, at most, five years of Spanish residency. About 3 percent of the sample is foreign-born and has these two characteristics. Overall, the figures in Table 3 reveal a few differences in age (a proxy for experience) and education by both nativity and gender. First, immigrants are, on average, 33 years old as opposed to natives, who are 40 years old on average. Second, a higher fraction of immigrant women work relative to native women (i.e. forty-five versus thirty-five, respectively). Third,

\footnotetext{
${ }^{5}$ Nonetheless, our results are robust to the inclusion of all immigrants since the vast majority of them are concentrated in occupations with greater manual task content.

${ }^{6}$ Those with a double nationality -less than 4 percent of all immigrants- are excluded from the analysis.
} 
there are also some differences in the educational attainment by nativity and gender. While there are not large educational differences among men, immigrant women appear more educated than their native female counterparts. Likewise, while natives have similar educational attainment, a higher fraction of immigrant women have a secondary education compared to immigrant men.

\subsection{Substitutability of Similarly Educated Workers by Nativity and Gender}

Tables 1 and 2 have shown that occupational distributions significantly differ by both gender and nativity. However, one could argue that such differences are driven by the human capital differences noted in Table 3. Therefore, Table 4 displays the occupational distribution of native men, native women, immigrant men and immigrant women according to whether they have a secondary education or less than a secondary education.

While the fraction of less educated workers in occupations requiring more skills (such as managers, professionals, technicians and professionals, or clerical support workers) is smaller, the occupational differences by nativity and gender noted in Table 1 and Table 2 still persist. In particular, immigrant men are more highly concentrated in non-skilled blue-collar occupations and less in skilled white-collar jobs than their native male counterparts. Likewise, immigrant women display a significantly higher concentration in blue-collar jobs and a lower presence in skilled white-collar jobs than native women. By gender, women are more concentrated in service and sales as well as in elementary occupations, whereas a higher fraction of men are employed in crafts and related trade jobs or as operators and assemblers.

In sum, the figures in Table 4 are suggestive of the imperfect substitutability of native men and immigrant men, as well as of native women and immigrant women of comparable educational attainment. Their distinct occupational distributions may be the result of their own sorting across occupations according to their comparative advantages. In particular, as Peri and Sparber (2008) suggest, most immigrants, due to their lack of language proficiency 
and other necessary production skills (interactive skills), may choose occupations that require fewer interactive skills (and a higher manual to non-manual task ratio) than natives. Likewise, women may avoid jobs that have strong physical demands and, instead, opt for jobs characterized by a lower manual to non-manual task content than those held by their male counterparts, making an analysis of the impact of immigration on the relative task supply of natives by both nativity and gender necessary.

\subsection{Measuring Task Specialization}

To examine whether immigration induces natives to relocate to jobs demanding fewer manual as opposed to interactive or non-manual skills, we rely on information on the job task requirements assembled by Peri and Sparber (2008). In their paper, Peri and Sparber (2008) merged data on job task requirements based on the U.S. Department of Labor's $O^{*} N e t$

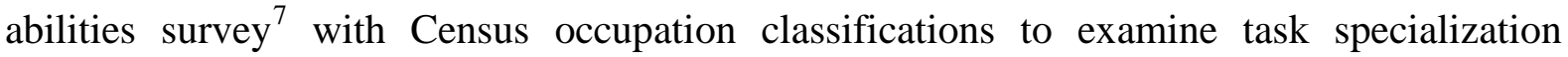
patterns of natives and immigrants in the U.S. ${ }^{8}$ They transform the $\mathrm{O}^{*} \mathrm{Net}$ abilities in percentile scores that represent the relative importance of each skill among all U.S. workers in 2000 .

We merge the $O^{*}$ Net abilities data to the Spanish labor force survey (i.e. Encuesta de Población Activa) by occupation. ${ }^{9}$ After properly weighting each occupation’s ability raw scores so as to reflect the importance of that particular ability in the Spanish labor force, we transform the ability scores into percentages to facilitate the interpretation of our findings. This is done by dividing each weighted ability score by the maximum score of the ability in question in other occupations. As such, each final ability score ranges between 0 and 1 and is

\footnotetext{
${ }^{7}$ They use version 11.0 of the survey, available at: http://www.onetcenter.org/

${ }^{8}$ The $O^{*} N E T$, initiated in the year 2000, rates the importance of 52 employee abilities -to which we refer to as tasks in this paper- in each occupation in the Standard Occupation Classification (SOC).

${ }^{9}$ U.S. 2000 Census codes in the $O^{*} N e t$ dataset are first matched to the International Standard Classification of Occupations (ISCO88) using a crosswalk made available by the Center for Longitudinal Studies in the U.K. at: http://www.cls.ioe.ac.uk/text.asp?section=00010001000500160002. Subsequently, the Spanish occupation codes (CNO94) are matched to ISCO88 codes. Finally, both datasets (the $O^{*} N e t$ abilities and the Spanish labor force survey) are then merged using the ISCO88 classification.
} 
indicative of the relative importance of that particular task in the occupation at hand -as opposed to its importance in other occupations.

Using the computed ability scores and taking into account that manual skills may differ by gender, ${ }^{10}$ we construct two measures (one narrower and one more broadly defined) of manual and interactive skills for men and two for women. In the case of men, we follow Peri and Sparber (2008), and define first a restricted measure of manual skills that contains the following abilities: "Limb, Hand, and Finger Dexterity", "Body Coordination and Flexibility”, and "Strength”. The broader measure of manual skills also adds "Sensory and Perception” abilities to the aforementioned skill categories. In the case of women, we exclude all those abilities that have to do with strength from the definition of manual skills of men. That is, the more restrictive measure of manual skills among women includes: "Limb, hand and finger dexterity" and "Body coordination and Flexibility", whereas the broader measure adds "Sensory and Perception" abilities to the other skill categories. Interactive skills, however, are defined in the same manner for both men and women. The restrictive measure includes measures of oral and written expression and comprehension, whereas the broader measure adds “Cognitive and Analytical” and "Vocal” abilities. ${ }^{11}$

Table 5 displays the restrictive manual and interactive task summary measures for each of the 2-digit ISCO88 occupations included in our analysis. As it would be expected, high skill occupations with lower classification codes have a greater content of interactive tasks and a smaller content of manual tasks than low skill occupations with higher classification codes. In contrast, low skill occupations with higher classification codes display, on average, a greater content of manual, as compared to interactive, tasks than the

\footnotetext{
${ }^{10}$ In particular, women may not have a comparative advantage in performing physically demanding jobs. Consequently, their choice of manual tasks may differ in composition from the choice of manual tasks made by their male counterparts.

${ }^{11}$ We acknowledge the arbitrary choices that one makes when trying to assign the $\mathrm{O}^{*} \mathrm{NET}$ skill variables into a manual vs. interactive task category. Hence, we also carry out the analysis using both the narrower and the more extended measures of manual and interactive skills.
} 
high skill occupations. As such, the figures in Table 5, along with those in Table 1, provide evidence of how, as assumed by the theoretical model, immigrants opt for jobs characterized by a greater manual to non-manual task content possibly due to their comparative advantage in non-manual as opposed to interactive tasks requiring communication skills. Likewise, possibly related to women's comparative disadvantage in performing physically demanding tasks, male and female occupation choices differ, even more so as we restrict our attention to occupations with higher manual to interactive task ratios.

\section{Methodology and Results}

Thus far, the descriptive statistics in Tables 1 through 5, along with Figures 1 and 2, have provided preliminary evidence of the greater relative supply of manual tasks by immigrants compared to natives, as well as of the distinct occupation choices of men and women. We now proceed to testing whether, as predicted by Figure 3, less educated native men and women have changed their occupational distribution, moving onto jobs characterized by a lower manual to non-manual task ratio, as the shares of similarly skilled foreign-born men and women rise.

To test this hypothesis, we collapse our data into region-time cells using data from 52 Spanish provinces from 9 years, i.e. from 1999-2007, and estimate the following regression equation:

$$
\ln \left(\frac{M}{I}\right)_{n, p t}=\alpha_{p}+\delta_{t}+X_{p t} \beta+\eta_{n}\left(\text { Share }_{-} \text {foreign }\right)_{p t}+\varepsilon_{p t}
$$

where $\alpha_{p}$ stands for the region (i.e. province) fixed-effects and $\delta_{t}$ for the year fixed-effects. Additionally, the vector $X_{p t}$ includes information on the average workers' personal characteristics of each cell (i.e. four age group dummies and a secondary-education dummy) 
to avoid potential spurious correlations between the immigration shock and the provision of manual to non-manual tasks by natives. ${ }^{12}$

Equation (1) examines the impact of the supply shock on the provision of relative manual tasks by less educated natives in the economy. If natives specialize in occupations requiring fewer manual, as opposed to interactive, tasks as the share of foreign-born workers increases, the coefficient $\eta_{n}$ should be negative and statistically different from zero.

To address any potential endogeneity between the relative supply of manual tasks by less educated natives and the supply shock, we re-estimate equation (1) instrumenting the share of low-educated foreign-born workers with information about the share of loweducated long-term immigrants -a group excluded from our sample object of analysis to ensure that immigrants in our sample significantly differ in their Spanish human capital from natives. We base our instrument choice for the share of foreign-born workers on a diversity of studies in the literature that show that settlement patterns of previous immigrants are a main determinant of immigrants’ location choices (e.g. Card 2001, Cortes 2006, Lewis 2003, Ottaviano and Peri 2006, Peri 2006, Saiz 2003, and Peri and Sparber 2008, among other ones, for similar strategies). Our instrument is strongly correlated to the share of foreign-born workers. Indeed, regardless of the task measure being used as the dependent variable, the first stage regressions from the two-stage instrumental variable estimation procedures yield coefficients that are statistically significant at the 1 percent level. ${ }^{13}$ Additionally, we informally assess whether the share of low-educated long-term immigrants is correlated with the error term in equation (1) by gauging its statistical significance in explaining the relative provision of manual tasks by natives other than via its impact on the share of low-educated

\footnotetext{
${ }^{12}$ Results are qualitatively the same to those derived from: (a) regressing each individual's task supply on a set of age and education dummies to compute the predicted task supply, (b) subtracting the predicted task supply from the individual's observed task supply to get the "cleaned" residuals, and (c) using the "cleaned" residuals to compute the manual and interactive task supply measures employed in the final regression analysis. We prefer this other method because it relies on the same exact manual and interactive skill measures already displayed in Table 5.

${ }^{13}$ First-stage results are available from the authors upon request.
} 
foreign-born workers. In all instances, regardless of whether we look at native men or women, the share of low-educated long-term immigrants turns out to be non-statistically different from zero in explaining the relative provision of manual tasks by natives once we control for the share of low-educated foreign-born workers. ${ }^{14}$

\subsection{Immigration and the Relative Task Supply of Native Men and Women}

Tables 6A and 6B display the results from estimating equation (1) separately for men and women using the four measures of the manual to non-manual task content described in the previous section, i.e. two narrower measures and two broader measures that differ in their inclusion of tasks requiring physical strength and sensory and perception abilities, respectively. In addition to using a variety of manual to non-manual task content measures, we estimate up to three different OLS specifications: (1) using the overall share of foreignborn workers, (2) using the share of either male or of female foreign-born workers in Tables $6 \mathrm{~A}$ and $6 \mathrm{~B}$, respectively, and (3) using the shares of male and of female foreign-born workers. Finally, we re-estimate the OLS specifications that provide the best fit, i.e. specifications (1) and (2), using the instrumental variable approach to address the endogeneity of the share of foreign-born workers and the task content of the occupations held by natives.

What are the key findings? The first result worth highlighting looking at the first and more general specification in Tables $6 \mathrm{~A}$ and $6 \mathrm{~B}$ is the negative impact that an increase in the share of foreign-born workers has on the manual to non-manual task content of the occupations held by native men and native women. This is true regardless of the task measure being used and methodology employed. The estimated IV impact is, however, generally greater than the estimated OLS effect, suggesting that the OLS estimate was biased downwards. In particular, a one standard deviation increase in the share of foreign-born

\footnotetext{
${ }^{14}$ These regression results are available from the authors.
} 
workers lowers the relative manual task supply of native workers anywhere between 0.7 to 0.9 percent in the case of men and between 2.1 to 2.3 percent among women. ${ }^{15}$ How do our estimates for Spain compare to the ones found for the U.S.? According to Peri and Sparber (2008), a one percentage-point increase in the foreign-born share of less educated workers increases the relative supply of communication versus manual tasks among men by 0.26 percent and the one of women by 0.11 percent. Note that the standard deviations of the shares of foreign-born male and female workers in Spain are approximately equal to 2 percentage-points and 3 percentage-points increases, respectively. Hence, the impacts of an increase in the share of foreign-born workers on the relative task supplies of native male and female workers in Spain are approximately 1.5 times and up to 7 times the estimated impacts of similar increases in the U.S.

A second finding worth noting from the results for the second and third model specifications in both tables is that the task content of the occupations held by native men (women) is solely impacted by the share of male (female) foreign-born workers, but never by the increase in the share of foreign-born workers from the opposite sex. This is true regardless of the task measure being used as the dependent variable or regardless of the methodology employed. More importantly, it underscores the significant extent of occupational segregation that exists by gender and confirms the need to acknowledge the distinct impact of immigrant men and women by examining the effect of an increase in the share of foreign-born workers on the relative task supply of native workers of the same sex.

Finally, a quick comparison of our findings using the four different task measures reveals that: (a) there are not large differences when we use the narrower versus the broader task content measures, which solely differ in their inclusion of sensory and perception abilities, and (b) the results are also quite similar regardless of whether we incorporate

\footnotetext{
${ }^{15}$ The standard deviations of the shares of foreign-born male and female workers are, respectively, 0.021 and 0.027 , i.e. approximately 2 and 3 percentage-points, respectively.
} 
measures of the physical strength required in the job in the case of men; however, they do differ among women. In particular, the impact of the share of foreign-born female workers on the relative manual supply of native female workers is greater when we exclude physical strength in the measure of manual skills. This finding suggests that this alternative definition of manual tasks may be a more adequate measure of manual skills when focusing on women.

In sum, the results from Table $6 \mathrm{~A}$ and $6 \mathrm{~B}$ indicate that an increase in the share of foreign-born workers and, in particular, of immigrant men and immigrant women induces native men and native women, respectively, to reduce their relative manual task supply by relocating to occupations with a lower manual to non-manual task content than those held by immigrants of the same sex. Are these findings specific to a particular group of workers? We address this question in the following sub-section.

\subsection{Findings for Specific Demographic Groups}

\subsubsection{Immigration and the Relative Task Supply of Natives by Age}

Because younger workers enjoy a higher occupational mobility than their older counterparts, it is reasonable to think that an increase in the share of foreign-born workers may have a greater impact among young natives. After all, younger workers may have accumulated less occupation-specific human capital and, therefore, may be less reticent to switch occupations and alter their relative manual task supply than older workers.

To examine whether this is indeed the case, we have repeated the analysis in Tables 6A and 6B distinguishing according to natives' ages. In particular, the figures in Table 7 display the results from estimating equation (1) using the log of manual to non-manual tasks provided, separately, by native men and women younger than 41 years of age and older than 40 years of age as our dependent variable. ${ }^{16}$ As in Table 6A and Table 6B, the analysis is performed using the four different task measures as well as using OLS and IV methods.

\footnotetext{
${ }^{16}$ A look at the data reveals that 41 years of age is the average age of working men, for instance.
} 
However, given our findings from Table 6A and 6B, we focus our attention on the impact that an increase in the share of male (female) foreign-born workers has on male (female) natives, i.e. specification no.2 in Tables 6A and 6B.

As expected, we find that an increase in the share of foreign-born male workers continues to lower the relative manual task supply of young native men, but not that of older men. Hence, younger men, possibly owing to their higher job mobility, have a greater response to an increase in the share of foreign-born male workers than older native men. Similarly, although all women appear responsive to an increase in the share of foreign-born female workers, the response seems larger among younger women likely to enjoy greater job mobility than their older counterparts.

\subsubsection{Immigration and the Relative Task Supply of Natives by Educational Attainment}

As with age, the impact of an increase in the share of foreign-born workers on the relative task supply of natives may differ according to the human capital of the latter. Even if we focus our analysis on workers with less than a college education, this is likely to include a very heterogeneous group of workers, from school dropouts to high-school educated workers. We would expect that natives with a higher educational attainment, i.e. high-school workers, might enjoy greater occupational mobility than high-school dropouts.

To examine whether this is the case, we re-estimate equation (1) separately for native men and native women with a secondary education and for native men and native women with less than a secondary education (i.e. with a primary education or less). As in Table 6A and Table 6B, the analysis is performed using the four different task measures as well as using OLS and IV methods. Likewise, we focus on the impact that an increase in the share of male (female) foreign-born workers has on male (female) natives, respectively. Table 8 displays the results. Immigration affects the relative task supply of native workers with a secondary education, but not that of native workers with a primary education or less. As 
such, it seems that only more educated natives have the human capital required to relocate and alter their relative task supply in response to an increase in the share of foreign-born workers.

\subsection{Immigration and Native Employment}

Thus far, we have found that an increase in the share of foreign-born workers reduces the relative supply of manual tasks offered by natives as they relocate to occupations with a lower manual to non-manual task content ratio. Hence, natives are simply switching occupations. However, one could ask whether immigration actually displaces native workers. In that case, an increase in the share of foreign-born workers should lower the employment level of natives. Although most regional analyses for the U.S. have been unable to find a significant impact of immigration on the employment of natives, we look at whether the same is observed in Spain. Our unit of analysis continues to be the (region, year) cell. Therefore, we regress the log of native employment on the share of foreign-born at the cell level. The analysis is carried out using OLS and IV methods. The results, available from the authors upon request, show that an increase in the share of foreign-born workers has a null impact on the employment of native men and women regardless of whether we disaggregate according to natives’ age or educational attainment. Instead, native workers appear to be adjusting by changing their task specialization and, as we show in what follows, by upgrading their occupations.

\section{Immigration and the Occupational Distribution of Native Men and Women}

As noted earlier, the analysis has, thus far, shown that natives respond to an increase in the share of foreign-born workers by relocating to occupations with a lower manual to nonmanual task content and, therefore, by reducing their relative supply of manual tasks. It is, nonetheless, interesting to know which occupations are natives leaving and which ones are they getting into. To address this question, we first compute the percentage of native men 
and women in each of the four following occupational categories in Table 2: (i) Skilled white-collar jobs (e.g. managerial and other professional occupations); (ii) Non-skilled whitecollar jobs (e.g. clerical and service jobs); (iii) Skilled blue-collar jobs (e.g. craftsmen, operators and assemblers); and (iv) Non-skilled blue-collar jobs (e.g. laborers in agriculture, construction, manufacturing and transportation, as well as domestic service personnel). Then, we estimate the impact of an increase in the share of foreign-born workers on the logarithm of the fraction of native workers in each category. The analysis is carried out at the (region, year) cell level and separately by gender.

Table 9 displays our findings. Generally, a one standard deviation increase in the share of foreign-born male workers reduces the fraction of native men in skilled blue-collar jobs by 0.5 percent and in non-skilled blue-collar jobs by 6 percent, while it raises the percentage of native men in skilled white-collar by 5 percent. Native women, on the other hand, leave non-skilled blue-collar jobs (mainly in domestic service) and move into skilled white-collar jobs (for the most part professionals such as teachers and nurses) in response to an increase in the share of foreign-born female workers. Specifically, a one standard deviation increase in the share of foreign-born female workers reduces the fraction of native women in non-skilled blue-collar jobs by 4 percent, whereas it raises the percentage of them in skilled white-collar jobs by 9 percent.

Due to the differential impact of immigration on the relative supply of manual tasks by natives depending on their age and educational attainment, we have repeated the analysis in Table 9 for different groups of natives, i.e. for workers ages 40 or younger and workers 41 years of age or older, as well as for workers with a secondary education and those with less. We display the results by natives' age in Table 10 . The figures in Table 10 indicate that a one standard deviation increase in the share of foreign-born male workers reduces the fraction of older native men in non-skilled blue-collar jobs by 6.6 percent and raises their 
presence in skilled white-collar jobs by 5 percent. In contrast, younger native female workers reduce their presence in non-skilled blue-collar jobs by 16 percent, whereas both younger and older native women raise their presence in skilled white-collar jobs by 10 percent and by 7 percent, respectively, in response to a one standard deviation increase in the share of foreignborn female workers.

How do the results vary according to natives' educational attainment? The figures in Table 11 address this question. An increase in the share of foreign-born male workers displaces less educated native men from non-skilled blue-collar jobs requiring only an elementary education. However, it is accompanied by an increase in the share of more educated native men in skilled white-collar jobs. In particular, using the IV estimates, a one standard deviation increase in the share of foreign-born male workers reduces the percent of native men with a primary education in non-skilled blue-collar jobs by 12.6 percent and increases the presence of native men with a secondary education in skilled white-collar jobs by 5.8 percent. In turn, native female workers with a secondary education seem to leave nonskilled blue-collar jobs for skilled white-collar jobs following an increase in foreign-born female workers. In particular, a one standard deviation increase in the share of foreign-born female workers reduces the fraction of native women with a secondary education in nonskilled blue-collar jobs by 6.7 percent and raises it in skilled white-collar jobs by 8.8 percent.

Hence, the results from Tables 10 and 11 reveal that, when there is an increase in the share of foreign-born male workers, older or less educated native men reduce their presence in non-skilled blue-collar jobs, while their older or more educated counterparts raise it in skilled white-collar jobs. In turn, younger as well as more educated native women leave nonskilled blue-collar jobs (mainly in domestic service), while more educated native women, regardless of age, move into skilled white-collar jobs (mostly teaching and nursing) in response to an increase in the share of foreign-born female workers. 


\section{Summary and Conclusions}

Previous immigration studies have long discussed a puzzling result, i.e. the fact that immigration appears to have very small wage effects and no employment effects on natives. Yet, if native and immigrant workers of similar educational attainment posses productive skills that lead them to specialize in different occupations, it is reasonable to find a null to small impact of immigration on the employment and wages of natives as immigrants and natives are not competing for the same jobs. Focusing on Spain, where immigration has more than doubled from 4 percent to roughly 10 percent of the population within a decade, we examine whether immigration has induced native workers to specialize in occupations that differ from those held by immigrants in their content of manual to non-manual tasks. However, unlike the existing literature, we also take note of the significant degree of occupational segregation by gender regardless of where workers were born and allow for male and female foreign-born workers to have distinct impacts on the employment patterns of native men and women. This proves to be important as foreign-born workers only seem to have a significant impact on the employment pattern of native workers of the same sex.

Using data from the 1999 through 2007 Encuestas de Población Activa (EPA), we first provide some descriptive evidence of the greater relative supply of manual tasks by immigrants compared to natives, as well as of the distinct occupation choices of men and women. These figures suggest that foreign-born male (female) workers are not perfect substitutes of similarly skilled native male (female) workers, which may help explain the null or small impacts of immigration on native employment and wages. Therefore, we then move to assess the impact of immigration on the relative task supply of Spanish natives. We find that immigration appears to have affected the task specialization of natives, inducing natives to relocate to jobs with a lower content of manual to non-manual tasks. A one standard deviation increase in the share of foreign-born workers is found to lower the relative manual 
task supply of native workers anywhere between 0.7 to 0.9 percent in the case of men and between 2.1 to 2.3 percent among women. However, due to the extent of occupational segregation by gender, the task content of the occupations held by native men (women) is solely impacted by the share of male (female) foreign-born workers, but never by the increase in the share of foreign-born workers from the opposite sex. This finding underscores the importance of examining the impact that an increase in the share of foreign-born workers has on the relative task supply of native workers of the same sex.

While our findings appear robust to alternative task measures or estimation methodologies, they vary with the age and educational attainment of native workers. In particular, as would be expected owing to their accumulated specific human capital, an increase in the share of foreign-born male workers lowers the relative manual task supply of young native men, but not that of older men, who may be more reticent to move. Similarly, younger women appear more responsive to an increase in the share of foreign-born female workers than their older counterparts. Finally, immigration appears to affect the relative task supply of native male and female workers with a secondary education, who possibly enjoy greater mobility owing to their higher human capital, but not that of their counterparts with a primary education or less.

Additionally, we take a closer look at the occupations that natives are leaving and getting into. We find that a one standard deviation increase in the share of foreign-born male workers reduces the fraction of native men in non-skilled and skilled blue-collar jobs by 6 percent and by 0.5 percent, respectively, whereas it raises the percentage of native men in skilled white-collar jobs by 5 percent. In the same vein, a one standard deviation increase in the share of foreign-born female workers reduces the fraction of native women in non-skilled blue-collar jobs (mainly in domestic service) by 4 percent, but raises the percent of native women in skilled white-collar jobs (mainly teachers and nurses) by 9 percent. 
As with the impact of immigration on the relative task supply of natives, these effects differ according to natives’ age and educational attainment. In particular, older or less educated native men reduce their presence in non-skilled blue-collar jobs, whereas older or more educated native men raise it in skilled white-collar jobs. In turn, younger and more educated native women leave non-skilled blue-collar jobs, while more educated native women, regardless of age, move into skilled white-collar jobs.

Overall, our findings have important labor market implications. First, they emphasize the importance of accounting for gender differences in the impact of immigration on natives' labor market outcomes. Second, they help us understand the apparent negligible impact of immigration on native wages and employment levels. Third, they suggest that, via adjustments in natives' task specialization and occupational upgrading, immigration may help increase job mobility, which could positively contribute to labor market efficiency by improving the quality of job matches (Raphael and Riker 1999). Finally, the results inform on some of the specific impacts of immigration in the host country labor market and, in particular, help predict occupational distribution changes among native men and women that may be crucial for future economic growth. 


\section{References}

Amuedo-Dorantes, Catalina and Sara De la Rica. 2008. "Does Immigration Raise Natives' Income? National and Regional Evidence from Spain”, IZA Discussion Paper \# 3486.

Borjas, George. 1994. “The Economics of Immigration,” Journal of Economic Literature, December 1994, pp. 1667-1717.

Borjas, George. 1995. “The Economic Benefits of Immigration”, Journal of Economic Perspectives, vol. 9, no. 2.

Borjas, George. 1999. “The Economic Analysis of Immigration,” in Handbook of Labor Economics, Volume 3A, edited by Orley Ashenfelter and David Card, North-Holland, pp. 1697-1760.

Borjas, George. 2003. "The Labor Demand Curve is Downward Sloping: Reexamining the impacts of Immigration on the Labor Market” Quarterly Journal of Economics, 118, pages: $1334-1374$.

Borjas, George. 2005. “The Labor Market Impact of High Skill Immigration,” American Economic Review, May.

Borjas, George and Larry Katz. 2007. "The Evolution of the Mexican-Born Workforce in the United States" (with Lawrence F. Katz), in Mexican Immigration to the United States, edited by George J. Borjas, University of Chicago Press.

Card, David. 1990. “The Impact of the Mariel Boatlift on the Miami Labor Market.” Industrial and Labor Relations Review, 43 (January 1990).

Card, David. 2001. "Immigrant Inflows, Native Outflows and the Local Labor Market Impacts of Higher Immigration” Journal of Labor Economics, 19 (January).

Card, David. 2005. “Is the New Immigration Really So Bad?” Economic Journal, 115.

Card, David and John E. Dinardo. 2000. “Do Immigrant Inflows Lead to Native Outflows?” American Economic Review, 90, May.

Card, David and Ethan Lewis. 2007. "The Diffusion of Mexican Immigrants During the 1990s: Explanations and Impacts." in Mexican Immigration to the United States, edited by George J. Borjas, University of Chicago Press.

Carrasco, Raquel, Juan F. Jimeno and A. C. Ortega (2008), "The effect of immigration on the labor market performance of native-born workers: some evidence for Spain”, Journal of Population Economics, 21, (3), pp: 627-649

Cortes, Patricia. 2006. How Low-Skilled Immigration Is Changing United States Prices and Labor Markets: Three Essays. Ph.D. Dissertation, Massachusetts Institute of Technology.

Gonzalez, Libertad and Francesc Ortega. 2007. "How do Very Open Economies Absorb Large Immigration Flows? Recent Evidence from Spanish Regions”, Mimeo. 
Lewis, Ethan. 2003. "Local Open Economies within the US: How do industries respond to Immigration?” Working Paper No. 04-1, Federal Reserve Bank of Philadelphia.

Ottaviano, Gianmarco and Giovanni Peri. 2005. "Rethinking the Gains from Immigration: Theory and Evidence from the U.S.” NBER Working Paper \# 11672.

Ottaviano, Gianmarco and Giovanni Peri. 2006. "Rethinking the Gains from Immigration on Wages” NBER Working Paper \# 12497.

Peri, Giovanni. 2006. “Immigrants’ Complementarities and Native Wages: Evidence from California”, Working Paper, University of California.

Peri, Giovanni and Chad Sparber. 2008. “Task Specialization, Immigration and Wages”, NBER Discussion Paper \# 02/08.

Raphael, Steven and David A. Riker. 1999. “Geographic Mobility, Race, and Wage Differentials” Journal of Urban Economics, 45(1): 17-46.

Saiz, Albert. 2003. "Room in the Kitchen for the Melting Pot: Immigration and Rental Prices,” Review of Economics and Statistics, 85:3, pp. 502-21. 
Figure 1

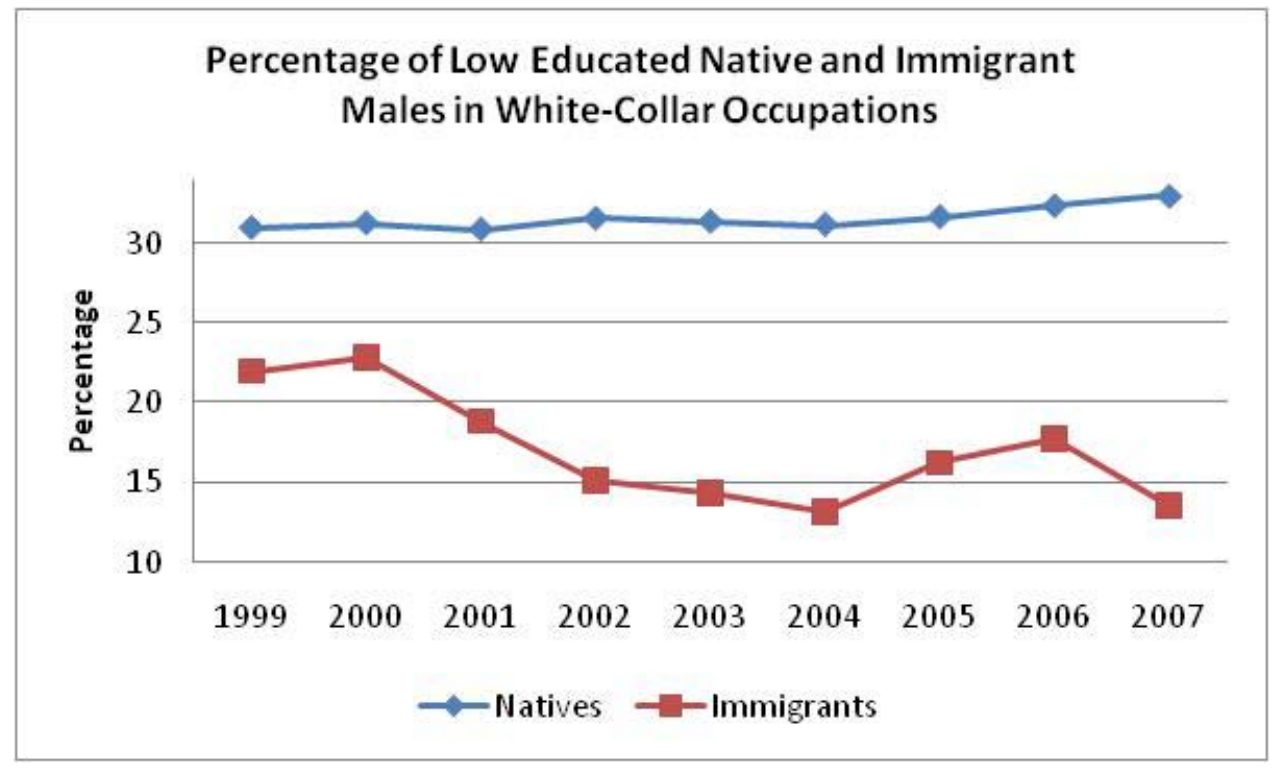

Figure 2

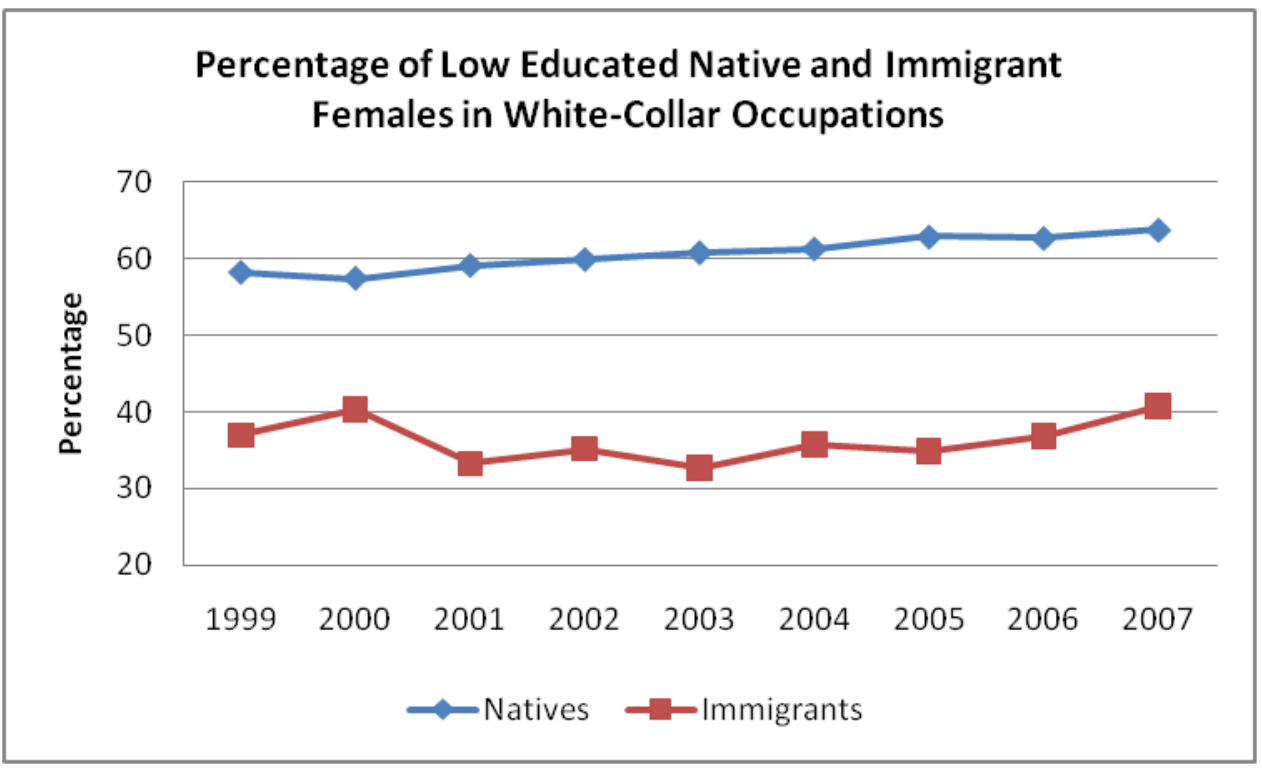


Figure 3

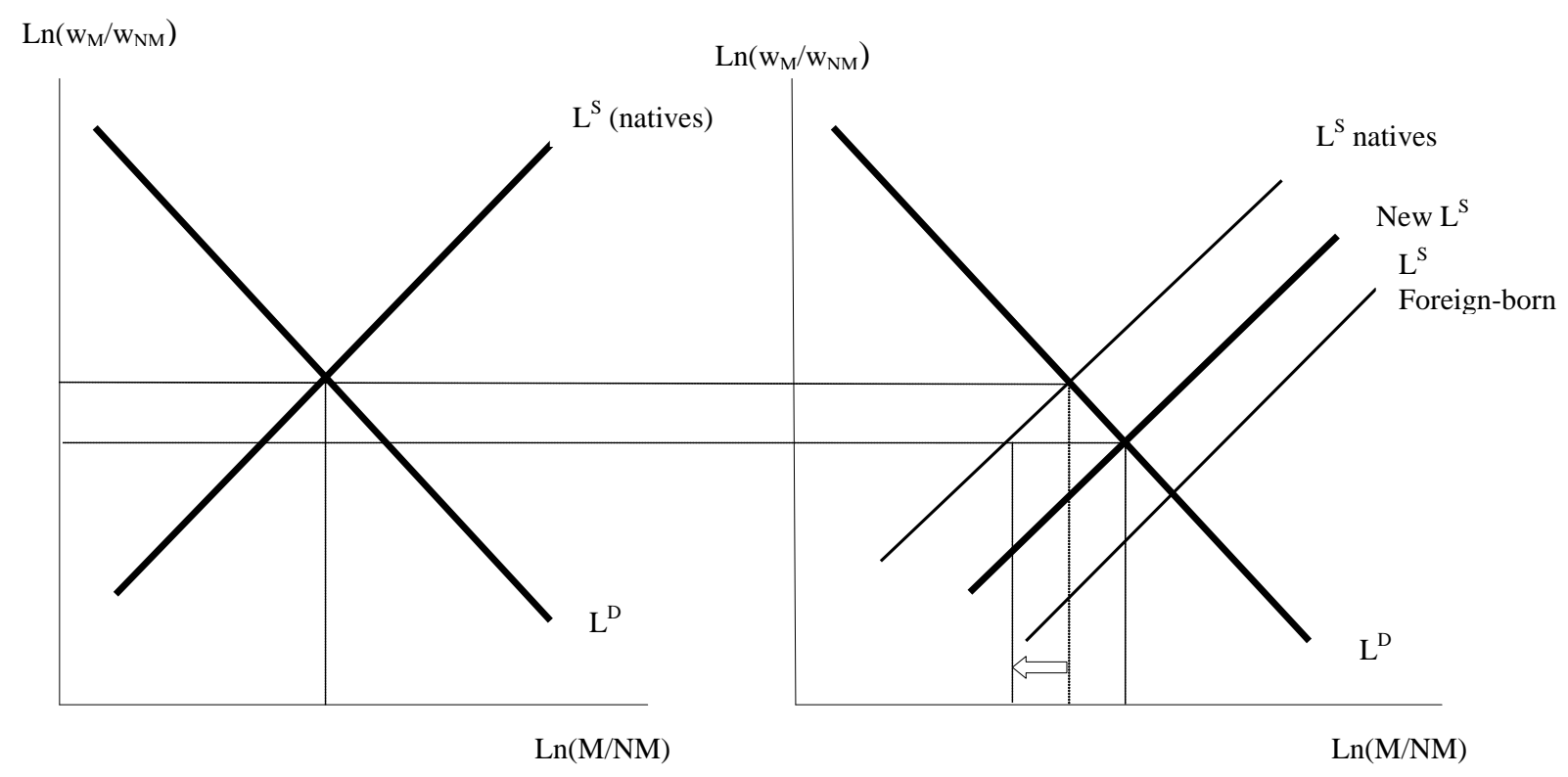


Table 1

Occupational Distribution by Gender and Nationality

\begin{tabular}{|c|c|c|c|c|c|}
\hline $\begin{array}{l}\text { Occupations } \\
\text { (ISCO88 code) }\end{array}$ & Average & Native Men & $\begin{array}{l}\text { Native } \\
\text { Women }\end{array}$ & $\begin{array}{l}\text { Immigrant } \\
\text { Men }\end{array}$ & $\begin{array}{l}\text { Immigrant } \\
\text { Women }\end{array}$ \\
\hline 12. Corporate Managers & 2.3 & 2.84 & 1.55 & 0.3 & 0.16 \\
\hline 13. Managers of Small Enterprises & 5.7 & 5.48 & 6.45 & 1.46 & 0.9 \\
\hline $\begin{array}{l}\text { 21. Physics, Mathematics and Engineering } \\
\text { Professionals }\end{array}$ & 0.07 & 0.10 & 0.04 & 0.02 & - \\
\hline 22. Life Science and Health Professionals & 0.02 & 0.01 & 0.02 & - & - \\
\hline 23. Teaching Professionals & 0.27 & 0.20 & 0.40 & 0.11 & 0.25 \\
\hline 24. Other Professionals & 0.21 & 0.22 & 0.19 & 0.15 & 0.09 \\
\hline $\begin{array}{l}\text { 31. Physical and Engineering Science } \\
\text { Associated Professionals }\end{array}$ & 1.04 & 1.36 & 0.49 & 0.50 & 0.05 \\
\hline $\begin{array}{l}\text { 32. Life Science and Health Associated } \\
\text { Professionals }\end{array}$ & 0.35 & 0.24 & 0.57 & 0.09 & 0.07 \\
\hline 33. Teaching Associated Professionals & 0.14 & 0.13 & 0.16 & 0.04 & 0.02 \\
\hline 34. Other Associated Professionals & 5.85 & 5.46 & 6.88 & 1.46 & 1.32 \\
\hline 41. Office Clerks & 3.92 & 3.25 & 5.39 & 0.62 & 0.62 \\
\hline 42. Customer Services Clerks & 4.10 & 1.93 & 8.30 & 0.54 & 2.68 \\
\hline $\begin{array}{l}\text { 51. Personal and Protective Service } \\
\text { Workers }\end{array}$ & 11.44 & 7.55 & 18.31 & 8.44 & 26.05 \\
\hline $\begin{array}{l}\text { 52. Models, Sales People and } \\
\text { Demonstrators }\end{array}$ & 6.15 & 3.06 & 12.08 & 2.00 & 4.3 \\
\hline $\begin{array}{l}\text { 61. Skilled Agriculture and Fishery } \\
\text { Workers }\end{array}$ & 5.88 & 7.04 & 3.97 & 3.51 & 0.65 \\
\hline $\begin{array}{l}\text { 71. Extraction and Building Trades } \\
\text { Workers }\end{array}$ & 11.23 & 17.00 & 0.43 & 23.5 & 0.21 \\
\hline $\begin{array}{l}\text { 72. Metal, Machinery and Related Trade } \\
\text { Workers }\end{array}$ & 0.24 & 0.36 & 2.01 & 0.07 & - \\
\hline $\begin{array}{l}\text { 73. Precision, Handicraft, Craft Printing } \\
\text { and Related Trades }\end{array}$ & 8.02 & 11.18 & 2.37 & 7.85 & 1.22 \\
\hline 74. Other Craft and Related Trade Workers & 1.79 & 1.80 & 1.8 & 1.98 & 1.04 \\
\hline 81. Stationary Plant and Related operators & 1.22 & 1.73 & 0.33 & 0.73 & 0.18 \\
\hline 82. Machine Operators and Assemblers & 4.72 & 4.90 & 4.49 & 2.76 & 1.41 \\
\hline 83. Drivers and Mobile Plant Operations & 6.91 & 10.56 & 0.41 & 5.01 & 0.14 \\
\hline $\begin{array}{l}\text { 91. Sales and Services Elementary } \\
\text { Operations }\end{array}$ & 9.91 & 3.76 & 20.28 & 4.5 & 50.6 \\
\hline 92. Agricultural and Fishery Labourers & 21.17 & 2.03 & 1.98 & 12.18 & 4.90 \\
\hline $\begin{array}{l}\text { 93. Labourers in Mining, Construction, } \\
\text { Manufacturing and Transportation }\end{array}$ & 6.30 & 7.76 & 3.10 & 22.17 & 3.09 \\
\hline Total Observations & 422998 & 268410 & 144905 & 5353 & 4330 \\
\hline
\end{tabular}

Notes: Working individuals between 16 and 65 years of age in the Spanish Labor Force Survey. Immigrants include only those with, at most, five years of residence in Spain, i.e. recent immigrants. 
Table 2

Distribution of Natives and Immigrants across Male and Female Native Occupations

\begin{tabular}{lcccc}
\hline \hline & Native Men & Native Women & Immigrant Men & Immigrant Women \\
\hline “Most Common Male Occupations” & & & & 2.2 \\
Skilled White-collar & 10.94 & 13.3 & 2.9 & 26.0 \\
Non-skilled White-collar & 7.55 & 18.3 & 8.4 & 3.6 \\
Skilled Blue-collar & 50.73 & 11.7 & 42.6 & 3.01 \\
Non-skilled Blue-collar & 9.79 & 5.1 & $\mathbf{3 0 . 4}$ \\
Total \% in These Occupations & $\mathbf{7 8 . 9}$ & $\mathbf{4 8 . 4}$ & $\mathbf{8 8 . 4}$ & \\
\hline & & & & 2.2 \\
“Most Common Female Occupations” & & & 33.6 \\
Skilled White-collar & 10.94 & 13.3 & 4.9 & 50.6 \\
Non-skilled White-collar & 15.7 & 44.1 & 4.5 & $\mathbf{8 6 . 5}$ \\
Blue-collar & 3.8 & 20.3 & $\mathbf{1 6 . 0}$ & \\
Total \% in These Occupations & $\mathbf{3 0 . 5}$ & $\mathbf{7 7 . 7}$ & & \\
\hline \hline
\end{tabular}

Notes: Working individuals between 16 and 65 years of age in the Spanish Labor Force Survey. Immigrants include only those with, at most, five years of residence in Spain, i.e. recent immigrants.

Most Common Male Occupations: Those where the percentage of native men is 5 percent or higher. The specific occupations included under each category are:

Skilled White-collar: $\quad$ 13: Managers of small enterprises.

34: Other Associate Professionals.

Non-skilled White-collar: 51: Personal and Protective Service Workers.

Skilled Blue-collar: $\quad$ 61: Skilled Agriculture and Fishery Workers.

71: Extraction and Building Trades Workers.

73: Precision, handicraft, Craft Printing and Related Trade

82: Machine Operators and Assemblers

83: Drivers and Mobile Plant Operators

Non-skilled Blue-collar: 92: Agricultural, fishery and related laborers

93: Laborers in Mining, Construction, Manuf. and Transportation.

Most Common Female Occupations: Those where the percentage of native women is 5 percent or higher. The specific occupations included under each category are:

Skilled White-collar: $\quad$ 13: Managers of small enterprises.

34: Other Associated professionals.

Non-skilled White-collar: 41: Office Clerks.

42: Customer Services Clerks

51: Personal and protective service workers.

52: Models, salespersons and demonstrators.

Blue-collar: $\quad$ 91: Sales and Services Elementary Operations. 
Table 3

Descriptive Statistics - Low Educated Natives and Immigrants (1999-2007)

\begin{tabular}{lcccc}
\hline Variables & $\begin{array}{c}\text { Native } \\
\text { Men }\end{array}$ & $\begin{array}{c}\text { Native } \\
\text { Women }\end{array}$ & $\begin{array}{c}\text { Male } \\
\text { Immigrants }\end{array}$ & $\begin{array}{c}\text { Female } \\
\text { Immigrants }\end{array}$ \\
\hline $\begin{array}{l}\text { Average Age } \\
\text { Distribution by age categories }\end{array}$ & 40.4 & 39.7 & 32.5 & 33.2 \\
(\%): & & & & \\
$<30$ years & 25.3 & 47.2 & 47.3 & 45.7 \\
31-35 years & 11.5 & 19.7 & 19.7 & 16.9 \\
36-40 years & 12.8 & 13.9 & 13.9 & 14.1 \\
41-45 years & 13.5 & 9.1 & 9.1 & 11.0 \\
$>45$ years & 36.9 & 10.1 & 10.0 & 12.3 \\
Percentage Female (\%) & & 35.0 & & 44.7 \\
Education (\%): & & & & \\
Primary or Less & 32.7 & 32.2 & 32.2 & 25.7 \\
Secondary & 67.2 & 67.7 & 67.8 & 74.3 \\
Observations (in Spanish LFS) & 268,409 & 144,905 & 5353 & 4330 \\
\hline \hline
\end{tabular}

Notes: Working individuals between 16 and 65 years of age in the Spanish Labor Force Survey. Immigrants include only those with, at most, five years of residence in Spain, i.e. recent immigrants. 
Table 4

Occupational Distribution (\%) of Natives and Immigrants by Educational Level

\begin{tabular}{|c|c|c|c|c|}
\hline & \multicolumn{4}{|c|}{ Secondary } \\
\hline & $\begin{array}{l}\text { Native } \\
\text { Men }\end{array}$ & $\begin{array}{l}\text { Native } \\
\text { Women }\end{array}$ & $\begin{array}{c}\text { Immigrant } \\
\text { Men }\end{array}$ & $\begin{array}{c}\text { Immigrant } \\
\text { Women }\end{array}$ \\
\hline Managers & 8.41 & 6.78 & 1.98 & 1.09 \\
\hline Professionals & 0.73 & 0.84 & 0.41 & 0.47 \\
\hline Technicians and professionals & 9.45 & 10.49 & 2.87 & 1.74 \\
\hline Clerical support workers & 6.59 & 17.48 & 1.27 & 4.01 \\
\hline Service and sales workers & 12.08 & 33.61 & 12.18 & 33.58 \\
\hline Skilled agricultural/fishery workers & 4.73 & 1.99 & 3.34 & 0.59 \\
\hline Craft and related trade workers & 28.96 & 4.26 & 34.95 & 2.24 \\
\hline Plant/machine operators and assemblers & 16.94 & 5.39 & 9.73 & 1.87 \\
\hline Elementary Occupations & 12.12 & 19.15 & 33.27 & 54.42 \\
\hline \multirow[t]{3}{*}{ N. observations } & 180,420 & 104,653 & 3628 & 3216 \\
\hline & \multicolumn{4}{|c|}{ Primary or Less } \\
\hline & $\begin{array}{l}\text { Native } \\
\text { Men }\end{array}$ & $\begin{array}{l}\text { Native } \\
\text { Women }\end{array}$ & $\begin{array}{c}\text { Immigrant } \\
\text { Men }\end{array}$ & $\begin{array}{c}\text { Immigrant } \\
\text { Women }\end{array}$ \\
\hline Managers & 8.15 & 11.19 & 1.28 & 0.99 \\
\hline Professionals & 0.13 & 0.16 & 0 & 0 \\
\hline Technicians and professionals & 2.53 & 1.88 & 0.46 & 0.63 \\
\hline Clerical support workers & 2.29 & 3.82 & 0.93 & 1.26 \\
\hline Service and sales workers & 7.61 & 22.00 & 6.78 & 21.01 \\
\hline Skilled agricultural/fishery workers & 11.79 & 9.13 & 3.88 & 0.81 \\
\hline Craft and related trade workers & 33.17 & 5.53 & 30.14 & 3.14 \\
\hline Plant/machine operators and assemblers & 17.86 & 4.78 & 5.91 & 1.35 \\
\hline Elementary Occupations & 16.47 & 41.51 & 50.61 & 70.83 \\
\hline N. observations & 87,989 & 40,252 & 1725 & 1114 \\
\hline
\end{tabular}

Notes: Working individuals between 16 and 65 years of age in the Spanish Labor Force Survey. Immigrants include only those with, at most, five years of residence in Spain, i.e. recent immigrants. 
Table 5

Tasks Intensity in each of the ISCO88-2digit Occupations

\begin{tabular}{|c|c|c|c|c|c|}
\hline $\begin{array}{l}\text { Occupations } \\
\text { (ISCO88 code) }\end{array}$ & $\begin{array}{l}\text { Manual } \\
\text { Males }\end{array}$ & $\begin{array}{l}\text { Manual } \\
\text { Females }\end{array}$ & Interactive & $\begin{array}{c}\text { Ratio } \\
\text { Manual/ } \\
\text { Interactive } \\
\text { Males }\end{array}$ & $\begin{array}{c}\text { Ratio } \\
\text { Manual/ } \\
\text { Interactive } \\
\text { Females }\end{array}$ \\
\hline 12. Corporate Managers & 0.49 & 0.47 & 0.99 & 0.49 & 0.47 \\
\hline 13. Managers of Small Enterprises & 0.49 & 0.45 & 0.95 & 0.52 & 0.47 \\
\hline $\begin{array}{l}\text { 21. Physics, Mathematics and Engineering } \\
\text { Professionals }\end{array}$ & 0.47 & 0.49 & 0.93 & 0.51 & 0.53 \\
\hline 22. Life Science and Health Professionals & 0.57 & 0.58 & 0.96 & 0.59 & 0.61 \\
\hline 23. Teaching Professionals & 0.54 & 0.48 & 0.94 & 0.58 & 0.51 \\
\hline 24. Other Professionals & 0.47 & 0.45 & 0.98 & 0.48 & 0.45 \\
\hline $\begin{array}{l}\text { 31. Physical and Engineering Science } \\
\text { Associated Professionals }\end{array}$ & 0.67 & 0.72 & 0.87 & 0.77 & 0.83 \\
\hline $\begin{array}{l}\text { 32. Life Science and Health Associated } \\
\text { Professionals }\end{array}$ & 0.67 & 0.66 & 0.91 & 0.73 & 0.72 \\
\hline 33. Teaching Associated Professionals & 0.48 & 0.48 & 0.85 & 0.56 & 0.56 \\
\hline 34. Other Associated Professionals & 0.48 & 0.47 & 0.94 & 0.51 & 0.51 \\
\hline 41. Office Clerks & 0.53 & 0.53 & 0.87 & 0.61 & 0.60 \\
\hline 42. Customer Services Clerks & 0.53 & 0.54 & 0.89 & 0.59 & 0.60 \\
\hline $\begin{array}{l}\text { 51. Personal and Protective Service } \\
\text { Workers }\end{array}$ & 0.71 & 0.66 & 0.84 & 0.85 & 0.78 \\
\hline $\begin{array}{l}\text { 52. Models, Sales People and } \\
\text { Demonstrators }\end{array}$ & 0.66 & 0.60 & 0.78 & 0.84 & 0.77 \\
\hline $\begin{array}{l}\text { 61. Skilled Agriculture and Fishery } \\
\text { Workers }\end{array}$ & 0.86 & 0.81 & 0.72 & 1.19 & 1.12 \\
\hline $\begin{array}{l}\text { 71. Extraction and Building Trades } \\
\text { Workers }\end{array}$ & 0.87 & 0.81 & 0.66 & 1.31 & 1.22 \\
\hline $\begin{array}{l}\text { 72. Metal, Machinery and Related Trade } \\
\text { Workers }\end{array}$ & 0.86 & 0.87 & 0.69 & 1.24 & 1.24 \\
\hline $\begin{array}{l}\text { 73. Precision, Handicraft, Craft Printing } \\
\text { and Related Trades }\end{array}$ & 0.81 & 0.87 & 0.62 & 1.29 & 1.39 \\
\hline 74. Other Craft and Related Trade Workers & 0.80 & 0.83 & 0.59 & 1.35 & 1.40 \\
\hline 81. Stationary Plant and Related operators & 0.86 & 0.88 & 0.69 & 1.25 & 1.29 \\
\hline 82. Machine Operators and Assemblers & 0.81 & 0.85 & 0.65 & 1.25 & 1.30 \\
\hline 83. Drivers and Mobile Plant Operations & 0.86 & 0.90 & 0.73 & 1.18 & 1.25 \\
\hline $\begin{array}{l}\text { 91. Sales and Services Elementary } \\
\text { Operations }\end{array}$ & 0.70 & 0.65 & 0.73 & 0.95 & 0.89 \\
\hline 92. Agricultural and Fishery Labourers & 0.91 & 0.86 & 0.58 & 1.56 & 1.47 \\
\hline $\begin{array}{l}\text { 93. Labourers in Mining, Construction, } \\
\text { Manufacturing and Transportation }\end{array}$ & 0.86 & 0.81 & 0.58 & 1.48 & 1.39 \\
\hline
\end{tabular}


Table 6A

Impact of the Share of Foreign Born on the Relative Supply of Manual Tasks by Native Men

\begin{tabular}{|c|c|c|c|c|c|}
\hline \multirow{2}{*}{$\begin{array}{l}\text { Tasks Measures } \\
\text { Task1 }_{\text {male }}:\end{array}$} & \multicolumn{3}{|c|}{ OLS } & \multicolumn{2}{|c|}{ IV } \\
\hline & & & & & \\
\hline Specification no.1 & $\begin{array}{c}-0.34^{* *} \\
(0.11)\end{array}$ & - & - & $\begin{array}{c}-0.40^{* *} \\
(0.19)\end{array}$ & - \\
\hline Specification no.2 & & $\begin{array}{c}-0.34^{* *} \\
(0.10)\end{array}$ & - & & $\begin{array}{l}-0.30^{*} \\
(0.17)\end{array}$ \\
\hline Specification no.3 & & $\begin{array}{l}-0.31^{* *} \\
(0.09)\end{array}$ & $\begin{array}{l}-0.04 \\
(0.11)\end{array}$ & & - \\
\hline \multicolumn{6}{|l|}{ Task1 $_{\text {female }}:$} \\
\hline Specification no.1 & $\begin{array}{c}-0.36^{* *} \\
(0.11)\end{array}$ & - & - & $\begin{array}{c}-0.35^{* *} \\
(0.17)\end{array}$ & - \\
\hline Specification no.2 & & $\begin{array}{c}-0.36^{* *} \\
(0.10)\end{array}$ & - & & $\begin{array}{l}-0.26^{*} \\
(0.15)\end{array}$ \\
\hline Specification no.3 & & $\begin{array}{c}-0.31^{* *} \\
(0.09)\end{array}$ & $\begin{array}{l}-0.06 \\
(0.12)\end{array}$ & & - \\
\hline \multicolumn{6}{|l|}{ Task2 $2_{\text {male }}$ : } \\
\hline Specification no.1 & $\begin{array}{c}-0.30^{* *} \\
(0.10)\end{array}$ & - & - & $\begin{array}{c}-0.43^{* *} \\
(0.19)\end{array}$ & - \\
\hline Specification no.2 & & $\begin{array}{c}-0.31^{* *} \\
(0.09)\end{array}$ & - & & $\begin{array}{l}-0.32^{*} \\
(0.18)\end{array}$ \\
\hline Specification no.3 & & $\begin{array}{c}-0.27^{* *} \\
(0.08)\end{array}$ & $\begin{array}{l}-0.04 \\
(0.10)\end{array}$ & & - \\
\hline \multicolumn{6}{|l|}{ Task $2_{\text {female }}$ : } \\
\hline Specification no.1 & $\begin{array}{c}-0.28^{* *} \\
(0.09)\end{array}$ & - & - & $\begin{array}{c}-0.34^{* *} \\
(0.16)\end{array}$ & - \\
\hline Specification no.2 & & $\begin{array}{l}-0.30^{* *} \\
(0.08)\end{array}$ & & & $\begin{array}{l}-0.24^{*} \\
(0.15)\end{array}$ \\
\hline Specification no.3 & & $\begin{array}{l}-0.25^{* *} \\
(0.08)\end{array}$ & $\begin{array}{l}-0.04 \\
(0.10)\end{array}$ & & - \\
\hline
\end{tabular}

Notes: Specification no.1 uses the overall share of foreign-born workers, Specification no.2 uses the share of male foreign-born workers, and Specification no.3 uses the share of male and the share of female foreign-born workers separately. All regressions include controls for average education and age at the cell level, as well as regional and time fixed effects (52 provinces and 8 years). Robust standard errors are clustered by province and displayed in parentheses. ${ }^{* *}$ stands for significance at $5 \%$ level or better and ${ }^{*}$ for significance at $10 \%$ level.

Task1 $1_{\text {male }}$ : The manual measure includes all skills connected with: "Limb, hand and finger dexterity", "Body coordination and Flexibility" and "Strength". Regarding the interactive measure, it includes the abilities related to "Oral and Written Expression", and "Comprehension”.

Task1 $1_{\text {female: }}$ : The manual measure includes all skills connected with: "Limb, hand and finger dexterity", "Body coordination and Flexibility" but all abilities related to "Strength" are excluded. Regarding communication skills, it includes "Oral and Written Expression”, and "Comprehension”.

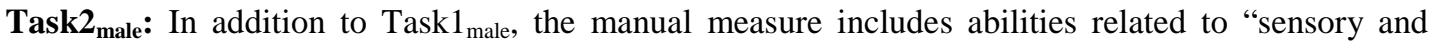
perception". As communication skills, it adds "Cognitive and Analytical” and "Vocal abilities".

Task $_{\text {female: }}$ : In addition to Task $1_{\text {female, }}$ the manual measure includes abilities related to "sensory and perception”. As communication skills, it adds "Cognitive and Analytical” and "Vocal abilities”. 
Table 6B

Impact of the Share of Foreign Born on the Relative Supply of Manual Tasks by Native Women

\begin{tabular}{|c|c|c|c|c|c|}
\hline Tasks Measures & & OLS & & & \\
\hline \multicolumn{6}{|l|}{ Task1 $_{\text {male: }}$} \\
\hline Specification no.1 & $\begin{array}{c}-0.47^{* *} \\
(0.16)\end{array}$ & - & - & $\begin{array}{c}-0.85^{* *} \\
(0.26)\end{array}$ & - \\
\hline Specification nо. 2 & & $\begin{array}{c}-0.50^{* *} \\
(0.16)\end{array}$ & - & & $\begin{array}{c}-0.63^{* *} \\
(0.31)\end{array}$ \\
\hline Specification no.3 & & $\begin{array}{c}-0.45^{* *} \\
(0.21)\end{array}$ & $\begin{array}{c}-0.05 \\
(0.14)\end{array}$ & & - \\
\hline \multicolumn{6}{|l|}{ Task1 $_{\text {female }}:$} \\
\hline Specification no.1 & $\begin{array}{c}-0.44^{* *} \\
(0.15)\end{array}$ & - & - & $\begin{array}{c}-0.71^{* *} \\
(0.23)\end{array}$ & - \\
\hline Specification no.2 & & $\begin{array}{c}-0.29^{* *} \\
(0.11)\end{array}$ & - & & $\begin{array}{c}-0.53^{* *} \\
(0.27)\end{array}$ \\
\hline Specification no.3 & & $\begin{array}{c}-0.43^{* *} \\
(0.21)\end{array}$ & $\begin{array}{c}-0.04 \\
(0.13)\end{array}$ & & - \\
\hline \multicolumn{6}{|l|}{ Task2 $2_{\text {male }}$} \\
\hline Specification no.1 & $\begin{array}{c}-0.39^{* *} \\
(0.14)\end{array}$ & - & - & $\begin{array}{c}-0.87^{* *} \\
(0.26)\end{array}$ & - \\
\hline Specification no. 2 & & $\begin{array}{c}-0.27^{* *} \\
(0.10)\end{array}$ & - & & $\begin{array}{c}-0.67^{* *} \\
(0.31)\end{array}$ \\
\hline Specification nо. 3 & & $\begin{array}{c}-0.38^{* *} \\
(0.18)\end{array}$ & $\begin{array}{c}-0.03 \\
(0.11)\end{array}$ & & - \\
\hline \multicolumn{6}{|l|}{ Task2 $_{\text {female }}$ : } \\
\hline Specification no.1 & $\begin{array}{c}-0.40^{* *} \\
(0.14)\end{array}$ & - & - & $\begin{array}{c}-0.77^{* * *} \\
(0.24)\end{array}$ & - \\
\hline Specification no.2 & & $\begin{array}{c}-0.27^{* *} \\
(0.10)\end{array}$ & & & $\begin{array}{c}-0.59^{* *} \\
(0.28)\end{array}$ \\
\hline Specification nо.3 & & $\begin{array}{c}-0.39^{* *} \\
(0.19)\end{array}$ & $\begin{array}{c}-0.03 \\
(0.12)\end{array}$ & & - \\
\hline
\end{tabular}

Notes: Specification no.1 uses the overall share of foreign-born workers, Specification no. 2 uses the share of male foreign-born workers, and Specification no.3 uses the share of male and the share of female foreign-born workers separately. All regressions include controls for average education and age at the cell level, as well as regional and time fixed effects (52 provinces and 8 years). Robust standard errors are clustered by province and displayed in parentheses. ${ }^{* *}$ stands for significance at $5 \%$ level or better and ${ }^{*}$ for significance at $10 \%$ level.

Task1 $1_{\text {male: }}$ The manual measure includes all skills connected with: "Limb, hand and finger dexterity", "Body coordination and Flexibility" and "Strength". Regarding the interactive measure, it includes the abilities related to "Oral and Written Expression", and "Comprehension".

Task1 $_{\text {female: }}$ The manual measure includes all skills connected with: "Limb, hand and finger dexterity", "Body coordination and Flexibility" but all abilities related to "Strength" are excluded. Regarding communication skills, it includes "Oral and Written Expression”, and "Comprehension".

Task $2_{\text {male: }}$ In addition to Task $1_{\text {male, }}$ the manual measure includes abilities related to "sensory and perception". As communication skills, it adds "Cognitive and Analytical" and "Vocal abilities".

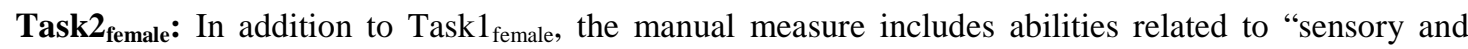
perception". As communication skills, it adds "Cognitive and Analytical" and "Vocal abilities". 
Table 7

Impact of the Share of Foreign Born on the Relative Supply of Manual Tasks of Natives by Age

\begin{tabular}{|c|c|c|c|c|}
\hline \multicolumn{5}{|c|}{ Workers Younger than 41} \\
\hline & \multicolumn{2}{|c|}{ Men } & \multicolumn{2}{|c|}{ Women } \\
\hline & OLS & IV & OLS & IV \\
\hline \multirow{2}{*}{ Task1 $_{\text {male }}$} & $-0.37^{* *}$ & $-0.31^{*}$ & $-0.33^{* *}$ & $-0.87^{*}$ \\
\hline & $(0.11)$ & $(0.18)$ & $(0.16)$ & $(0.45)$ \\
\hline \multirow{2}{*}{ Task1 $_{\text {female }}$} & $-0.40^{* *}$ & $-0.37^{*}$ & $-0.35^{* *}$ & $-0.79^{*}$ \\
\hline & $(0.11)$ & $(0.19)$ & $(0.17)$ & $(0.42)$ \\
\hline \multirow[t]{2}{*}{ Task2 $2_{\text {male }}$} & $-0.33^{* *}$ & $-0.27^{*}$ & $-0.29^{* *}$ & $-0.77^{*}$ \\
\hline & $(0.10)$ & $(0.17)$ & $(0.15)$ & $(0.40)$ \\
\hline \multirow[t]{2}{*}{ Task $2_{\text {female }}$} & $-0.32^{* *}$ & $-0.28^{*}$ & $-0.29^{* *}$ & $-0.68^{*}$ \\
\hline & $(0.09)$ & $(0.16)$ & $(0.15)$ & $(0.38)$ \\
\hline \multicolumn{5}{|c|}{ Workers Older than 40} \\
\hline & \multicolumn{2}{|c|}{ Men } & \multicolumn{2}{|c|}{ Women } \\
\hline & OLS & IV & OLS & IV \\
\hline \multirow[t]{2}{*}{ Task1 $_{\text {male }}$} & $-0.28^{* *}$ & -0.26 & $-0.23^{* *}$ & $-0.55^{*}$ \\
\hline & $(0.12)$ & $(0.25)$ & $(0.12)$ & $(0.34)$ \\
\hline \multirow[t]{2}{*}{ Task1 $_{\text {female }}$} & $-0.26^{* *}$ & -0.23 & $-0.23^{* *}$ & $-0.55^{*}$ \\
\hline & $(0.12)$ & $(0.25)$ & $(0.12)$ & $(0.34)$ \\
\hline \multirow[t]{2}{*}{ Task $2_{\text {male }}$} & $-0.24^{* *}$ & -0.21 & $-0.21^{* *}$ & $-0.49^{*}$ \\
\hline & $(0.11)$ & $(0.22)$ & $(0.11)$ & $(0.31)$ \\
\hline \multirow[t]{2}{*}{ Task $_{\text {female }}$} & $-0.21^{* *}$ & -0.19 & $-0.19^{* *}$ & $-0.47^{*}$ \\
\hline & $(0.10)$ & $(0.21)$ & $(0.10)$ & $(0.29)$ \\
\hline
\end{tabular}

Notes: Each of the coefficients reported in the table is the result of a different estimation. For men, the share of foreign born male workers is used and, for women, the share of foreign born female workers. All regressions include controls for average education and age at the cell level, as well as regional and time fixed effects (52 provinces and 8 years). Robust standard errors are clustered by province and displayed in parentheses. ${ }^{* *}$ stands for significance at $5 \%$ level or better and ${ }^{*}$ for significance at $10 \%$ level. 
Table 8

Impact of the Share of Foreign Born on the Relative Supply of Manual Tasks of Natives by Educational Attainment

\begin{tabular}{|c|c|c|c|c|}
\hline \multicolumn{5}{|c|}{ Less than High-School } \\
\hline & \multicolumn{2}{|c|}{ Men } & \multicolumn{2}{|c|}{ Women } \\
\hline & OLS & IV & OLS & IV \\
\hline \multirow[t]{2}{*}{ Task1 $_{\text {male }}$} & -0.159 & -0.117 & -0.088 & -0.637 \\
\hline & $(0.154)$ & $(0.30)$ & $(0.14)$ & $(0.45)$ \\
\hline \multirow[t]{2}{*}{ Task1 $_{\text {female }}$} & -0.164 & -0.119 & -0.110 & -0.633 \\
\hline & $(0.158)$ & $(0.30)$ & $(0.14)$ & $(0.42)$ \\
\hline \multirow[t]{2}{*}{ Task2 $2_{\text {male }}$} & -0.137 & -0.076 & -0.100 & -0.550 \\
\hline & $(0.138)$ & $(0.27)$ & $(0.12)$ & $(0.37)$ \\
\hline \multirow[t]{2}{*}{ Task2 $_{\text {female }}$} & -0.129 & -0.066 & -0.09 & -0.583 \\
\hline & $(0.132)$ & $(0.25)$ & $(0.13)$ & $(0.39)$ \\
\hline
\end{tabular}

High-School

\begin{tabular}{|c|c|c|c|c|}
\hline & \multicolumn{2}{|c|}{ Men } & \multicolumn{2}{|c|}{ Women } \\
\hline & OLS & IV & OLS & IV \\
\hline \multirow[t]{2}{*}{ Task1 $_{\text {male }}$} & $-0.432^{* *}$ & $-0.351^{* *}$ & $-0.467^{* *}$ & $-0.748^{* *}$ \\
\hline & $(0.11)$ & (0.179) & $(0.13)$ & $(0.32)$ \\
\hline \multirow[t]{2}{*}{ Task $_{\text {female }}$} & $-0.459^{* *}$ & $-0.374^{* *}$ & $-0.484^{* *}$ & $-0.704^{* *}$ \\
\hline & $(0.11)$ & (0.18) & $(0.13)$ & $(0.33)$ \\
\hline \multirow{2}{*}{ Task $2_{\text {male }}$} & $-0.390^{* *}$ & $-0.314^{* *}$ & $-0.427^{* *}$ & $-0.67^{* *}$ \\
\hline & $(0.09)$ & $(0.16)$ & $(0.12)$ & $(0.29)$ \\
\hline \multirow[t]{2}{*}{ Task $_{\text {female }}$} & $-0.378^{* *}$ & $-0.304^{* *}$ & $-0.407^{* *}$ & $-0.601^{* *}$ \\
\hline & $(0.09)$ & $(0.15)$ & $(0.11)$ & $(0.28)$ \\
\hline
\end{tabular}

Notes: Each of the coefficients reported in the table is the result of a different estimation. For men, the share of foreign born male workers is used and, for women, the share of foreign born female workers. All regressions include controls for average education and age at the cell level, as well as regional and time fixed effects (52 provinces and 8 years). Robust standard errors are clustered by province and displayed in parentheses. ${ }^{* *}$ stands for significance at $5 \%$ level or better and ${ }^{*}$ for significance at $10 \%$ level. 
Table 9

Impact of the Share of Foreign Born on the Occupational Distribution of Natives

\begin{tabular}{lcccc}
\hline \hline & \multicolumn{2}{c}{ Men } & \multicolumn{2}{c}{ Women } \\
& OLS & IV & OLS & IV \\
\hline $\begin{array}{l}\text { Skilled White-Collar Jobs } \\
\text { (e.g. Mangers, Professionals and Technicians) }\end{array}$ & $1.87^{* *}$ & $2.54^{* *}$ & $1.78^{* *}$ & $3.44^{* *}$ \\
& $(0.77)$ & $(1.20)$ & $(0.75)$ & $(1.20)$ \\
$\begin{array}{l}\text { Non-Skilled White-Collar Jobs } \\
\text { (e.g. Clerical Support, Service and Sales Workers) }\end{array}$ & -0.00 & -0.28 & 0.41 & -0.16 \\
& $(0.81)$ & $(0.96)$ & $(0.56)$ & $(1.11)$ \\
$\begin{array}{l}\text { Skilled Blue-Collar Jobs } \\
\text { (e.g. Craftsmen, Operators and Assemblers) }\end{array}$ & -0.09 & $-0.25^{*}$ & -1.44 & -0.01 \\
& $(0.28)$ & $(0.56)$ & $(1.23)$ & $(2.45)$ \\
$\begin{array}{l}\text { Non-Skilled Blue-Collar Jobs } \\
\text { (e.g. Labourers and Domestic Service Personnel) }\end{array}$ & $-2.31^{* *}$ & $-2.80^{* *}$ & $-1.03^{*}$ & $-1.58^{*}$ \\
& $(1.13)$ & $(1.39)$ & $(0.60)$ & $(1.00)$ \\
\hline \hline
\end{tabular}

Notes: Each of the coefficients reported in the table is the result of a different estimation. The dependent variable is the logarithm of the fraction of natives in each occupational category at the cell level (i.e. by province and year). For men, the share of foreign born male workers in each cell is used and, for women, the share of foreign born female workers. All regressions include controls for average education and age at the cell level, as well as regional and time fixed effects (52 provinces and 8 years). Robust standard errors are clustered by province and displayed in parentheses. ${ }^{* *}$ stands for significance at $5 \%$ level or better and ${ }^{*}$ for significance at $10 \%$ level. 
Table 10

Impact of the Share of Foreign Born on the Occupational Distribution of Natives by Age

\begin{tabular}{|c|c|c|c|c|}
\hline \multicolumn{5}{|c|}{ Workers Younger than 41} \\
\hline & \multicolumn{2}{|c|}{ Men } & \multicolumn{2}{|c|}{ Women } \\
\hline & OLS & IV & OLS & IV \\
\hline $\begin{array}{l}\text { Skilled White-Collar Jobs } \\
\text { (e.g. Mangers, Professionals and Technicians) }\end{array}$ & $\begin{array}{c}0.92 \\
(1.11)\end{array}$ & $\begin{array}{l}2.55 \\
(1.85)\end{array}$ & $\begin{array}{l}2.04^{* *} \\
(1.07)\end{array}$ & $\begin{array}{l}3.83^{*} \\
(2.42)\end{array}$ \\
\hline $\begin{array}{l}\text { Non-Skilled White-Collar Jobs } \\
\text { (e.g. Clerical Support, Service and Sales Workers) }\end{array}$ & $\begin{array}{l}-1.08 \\
(1.16)\end{array}$ & $\begin{array}{l}-2.26 \\
(1.63)\end{array}$ & $\begin{array}{c}0.88^{*} \\
(0.56)\end{array}$ & $\begin{array}{c}1.01 \\
(0.96)\end{array}$ \\
\hline $\begin{array}{l}\text { Skilled Blue-Collar Jobs } \\
\text { (e.g. Craftsmen, Operators and Assemblers) }\end{array}$ & $\begin{array}{c}0.50 \\
(0.34)\end{array}$ & $\begin{array}{c}0.48 \\
(0.56)\end{array}$ & $\begin{array}{l}-1.63 \\
(2.14)\end{array}$ & $\begin{array}{c}1.04 \\
(3.79)\end{array}$ \\
\hline $\begin{array}{l}\text { Non-Skilled Blue-Collar Jobs } \\
\text { (e.g. Labourers and Domestic Service Personnel) }\end{array}$ & $\begin{array}{l}-2.18^{*} \\
(1.24)\end{array}$ & $\begin{array}{l}-1.97 \\
(1.48)\end{array}$ & $\begin{array}{l}-2.12^{* *} \\
(1.05)\end{array}$ & $\begin{array}{c}-5.82^{* *} \\
(1.71)\end{array}$ \\
\hline \multicolumn{5}{|c|}{ Workers Older than 40} \\
\hline & \multicolumn{2}{|c|}{ Men } & \multicolumn{2}{|c|}{ Women } \\
\hline & OLS & IV & OLS & IV \\
\hline $\begin{array}{l}\text { Skilled White-Collar Jobs } \\
\text { (e.g. Mangers, Professionals and Technicians) }\end{array}$ & $\begin{array}{l}2.38^{* *} \\
(0.84)\end{array}$ & $\begin{array}{l}2.28^{*} \\
(1.30)\end{array}$ & $\begin{array}{c}1.39 \\
(0.46)\end{array}$ & $\begin{array}{l}2.53^{* *} \\
(1.77)\end{array}$ \\
\hline $\begin{array}{l}\text { Non-Skilled White-Collar Jobs } \\
\text { (e.g. Clerical Support, Service and Sales Workers) }\end{array}$ & $\begin{array}{c}0.84 \\
(0.79)\end{array}$ & $\begin{array}{c}1.21 \\
(1.56)\end{array}$ & $\begin{array}{c}0.19 \\
(0.65)\end{array}$ & $\begin{array}{l}-1.00 \\
(1.49)\end{array}$ \\
\hline $\begin{array}{l}\text { Skilled Blue-Collar Jobs } \\
\text { (e.g. Craftsmen, Operators and Assemblers) }\end{array}$ & $\begin{array}{l}-0.58^{* *} \\
(0.30)\end{array}$ & $\begin{array}{l}-0.79 \\
(0.85)\end{array}$ & $\begin{array}{l}-1.85 \\
(1.06)\end{array}$ & $\begin{array}{l}-0.35 \\
(2.06)\end{array}$ \\
\hline $\begin{array}{l}\text { Non-Skilled Blue-Collar Jobs } \\
\text { (e.g. Labourers and Domestic Service Personnel) }\end{array}$ & $\begin{array}{l}-2.64^{* *} \\
(1.30)\end{array}$ & $\begin{array}{l}-3.14^{*} \\
(2.00)\end{array}$ & $\begin{array}{l}-1.10^{*} \\
(0.65)\end{array}$ & $\begin{array}{l}-0.42 \\
(1.12)\end{array}$ \\
\hline
\end{tabular}

Notes: Each of the coefficients reported in the table is the result of a different estimation. The dependent variable is the logarithm of the fraction of natives in each occupational category at the cell level (i.e. by province and year). For men, the share of foreign born male workers in each cell is used and, for women, the share of foreign born female workers. All regressions include controls for average education and age at the cell level, as well as regional and time fixed effects (52 provinces and 8 years). Robust standard errors are clustered by province and displayed in parentheses. ${ }^{* *}$ stands for significance at $5 \%$ level or better and ${ }^{*}$ for significance at $10 \%$ level. 
Table 11

Impact of the Share of Foreign Born on the Occupational Distribution of Natives

by Educational Attainment

\section{Less than High-School}

\begin{tabular}{|c|c|c|c|c|}
\hline & \multicolumn{2}{|c|}{ Men } & \multicolumn{2}{|c|}{ Women } \\
\hline & OLS & IV & OLS & IV \\
\hline $\begin{array}{l}\text { Skilled White-Collar Jobs } \\
\text { (e.g. Mangers, Professionals and Technicians) }\end{array}$ & $\begin{array}{l}-0.59 \\
(2.24)\end{array}$ & $\begin{array}{l}1.35 \\
(2.90)\end{array}$ & $\begin{array}{l}-0.14 \\
(1.41)\end{array}$ & $\begin{array}{c}0.54 \\
(1.94)\end{array}$ \\
\hline $\begin{array}{l}\text { Non-Skilled White-Collar Jobs } \\
\text { (e.g. Clerical Support, Service and Sales Workers) }\end{array}$ & $\begin{array}{l}3.21^{* *} \\
(1.66)\end{array}$ & $\begin{array}{c}1.01 \\
(3.69)\end{array}$ & $\begin{array}{l}-0.39 \\
(0.93)\end{array}$ & $\begin{array}{l}-1.45 \\
(1.79\end{array}$ \\
\hline $\begin{array}{l}\text { Skilled Blue-Collar Jobs } \\
\text { (e.g. Craftsmen, Operators and Assemblers) }\end{array}$ & $\begin{array}{c}0.28 \\
(0.42)\end{array}$ & $\begin{array}{c}1.04 \\
(0.98)\end{array}$ & $\begin{array}{l}-1.75 \\
(1.31)\end{array}$ & $\begin{array}{l}-2.29 \\
(2.21)\end{array}$ \\
\hline $\begin{array}{l}\text { Non-Skilled Blue-Collar Jobs } \\
\text { (e.g. Labourers and Domestic Service Personnel) }\end{array}$ & $\begin{array}{l}-3.40^{* *} \\
(1.76)\end{array}$ & $\begin{array}{l}-6.00^{* *} \\
(2.70)\end{array}$ & $\begin{array}{c}0.54 \\
(0.61)\end{array}$ & $\begin{array}{c}1.11 \\
(1.03)\end{array}$ \\
\hline \multicolumn{5}{|c|}{ High-School } \\
\hline & \multicolumn{2}{|c|}{ Men } & \multicolumn{2}{|c|}{ Women } \\
\hline & OLS & IV & OLS & IV \\
\hline $\begin{array}{l}\text { Skilled White-Collar Jobs } \\
\text { (e.g. Mangers, Professionals and Technicians) }\end{array}$ & $\begin{array}{l}1.95^{* *} \\
(0.76)\end{array}$ & $\begin{array}{l}2.75^{* *} \\
(1.45)\end{array}$ & $\begin{array}{l}1.80^{* *} \\
(0.82)\end{array}$ & $\begin{array}{l}3.26^{* *} \\
(1.27)\end{array}$ \\
\hline $\begin{array}{l}\text { Non-Skilled White-Collar Jobs } \\
\text { (e.g. Clerical Support, Service and Sales Workers) }\end{array}$ & $\begin{array}{l}-0.58 \\
(0.85\end{array}$ & $\begin{array}{l}-0.54 \\
(1.13)\end{array}$ & $\begin{array}{l}0.91^{*} \\
(0.58)\end{array}$ & $\begin{array}{c}0.54 \\
(1.10)\end{array}$ \\
\hline $\begin{array}{l}\text { Skilled Blue-Collar Jobs } \\
\text { (e.g. Craftsmen, Operators and Assemblers) }\end{array}$ & $\begin{array}{l}-0.14 \\
(0.33)\end{array}$ & $\begin{array}{l}-0.36 \\
(0.57)\end{array}$ & $\begin{array}{l}-1.46^{* *} \\
(1.73)\end{array}$ & $\begin{array}{c}0.07 \\
(3.20)\end{array}$ \\
\hline $\begin{array}{l}\text { Non-Skilled Blue-Collar Jobs } \\
\text { (e.g. Labourers and Domestic Service Personnel) }\end{array}$ & $\begin{array}{c}-1.77^{* *} \\
(1.15)\end{array}$ & $\begin{array}{l}-1.43 \\
(1.48)\end{array}$ & $\begin{array}{c}-1.97^{* *} \\
(0.76)\end{array}$ & $\begin{array}{c}-2.49^{* *} \\
(1.28)\end{array}$ \\
\hline
\end{tabular}

Notes: Each of the coefficients reported in the table is the result of a different estimation. The dependent variable is the logarithm of the fraction of natives in each occupational category at the cell level (i.e. by province and year). For men, the share of foreign born male workers in each cell is used and, for women, the share of foreign born female workers. All regressions include controls for average education and age at the cell level, as well as regional and time fixed effects (52 provinces and 8 years). Robust standard errors are clustered by province and displayed in parentheses. ${ }^{* *}$ stands for significance at $5 \%$ level or better and ${ }^{*}$ for significance at $10 \%$ level. 